\title{
Job Applicants Preference Towards Selection of Employment- A Study in Tirupur Garment Industries
}

\author{
P. Sankarakarthikeyan', Balaji. M², K. Prabha Kumari ${ }^{1}$ \\ ${ }^{1}$ Assistant Professor, ${ }^{2}$ Student \\ 1,2Department of Apparel Manufacturing and Merchandising, \\ 1,2NIFT-TEA College of Knitwear Fashion, Tirupur, Tamil Nadu, India
}

\begin{abstract}
How to cite this paper: $\mathrm{P}$. Sankarakarthikeyan | Balaji. M | K. Prabha Kumari "Job Applicants Preference Towards Selection of Employment - A Study in Tirupur Garment Industries" Published in International Journal of Trend in Scientific Research and Development (ijtsrd), ISSN: 24566470, Volume-3 | Issue-3, April 2019, pp.359-361, URL: http://www.ijtsrd.co $\mathrm{m} /$ papers/ijtsrd217 67.pdf

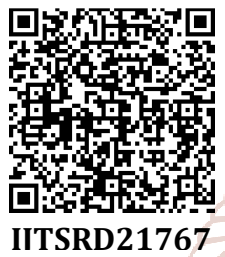

Copyright (C) 2019 by author(s) and International Journal of Trend in Scientific Research and Development Journal. This is an Open Access article distributed under the terms of the Creative Commons

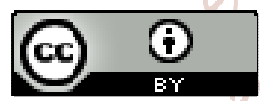
Attribution License (CC BY 4.0) (http://creativecommons.org/licenses/ by/4.0)

\section{INTRODUCTION}

In the ever increasing competition in the employment market, an organization's need to become a "great place to work" has gained significant momentum. Employer branding has thus emerged as an essential management practice employed by the organization to create its image as desirable employer in the eyes of prospective employees.

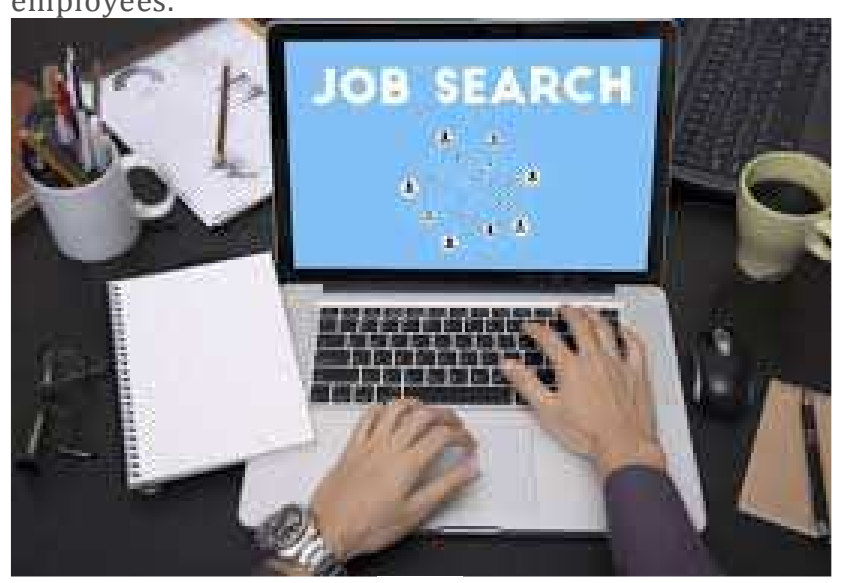

Fig: 1

\section{ABSTRACT}

Work is an integral part of everyday life, as it is our livelihood or career or business. On an average we spent twelve hours daily life and it is the one third of our entire life. The Preference of work in selected garment industries is very important by considering the factors like Infrastructure, pay scale, Transportation, company locations , Interpersonal relationship with Superiors and Housing facilities of the organization. The preference of job is the important aspect for the human resource for selecting the new venture in the organization. The Quality of work life is considered for both the employees and organization and it is involved with job satisfaction, productivity, job involvement, job enrichment etc. Every organization's success is highly dependent on how it attracts recruits, motivates, and retains its workforce. Today's organizations need to be more flexible so that they are equipped to develop their workforce and enjoy their commitment. In this study the Researcher analyze the preference of selecting job in Tirupur garment industries and certain recommendations given to the fresher's to give preference for effective job in Garment industries.

\section{Keywords: Preference, job, Organization Productivity, Organization culture}

The purpose of this study is to highlight the understanding of employer branding through the eyes of "potential" young employees in Tirupur. The results presented in this paper throw light on the perceived importance of employer branding among the prospective fresher's for the study.

\section{OBJECTIVES OF THE STUDY:}

$>$ To study the demographic profile of the employees in small scale garment industries.

$>$ To identify the expectation of the employees to the employer of the Garment industry

$>$ To analyse the job Applicants mindset.

Need of the study

1. Analysing the job aligns with your long term career goals.

2. Financial Incentices with personal satisfaction.

3. Assess the culture of each workplace.

4. Trust your intuition towards the Work place.

\section{Limitations of the Study:}

$>$ The study is restricted to the selected employees of Tirupur District who were working in small scale 
$>$ Garments industries and hence the result of the study cannot be generalized.

$>$ The statistical methods used to analyze the data have their own limitation.

$>$ All the limitations of primary data are applicable to this study.

\section{REVIEW OF LITERATURE:}

Zohurul Islam, SununtaSiengthai(2011)

"Quality of work life and organizational performance: Empirical evidence from Dhaka Export Processing Zone "This study identifies factors that are associated with employees'job satisfaction and Quality of Work Life of Dhaka Export Processing Zone for organizational performance.

\section{A Stephen, D Dhanapal (2011)}

in the paper "Quality of Work Life and its impact on Organisational Excellence in Small Scale Industrial Units: Employers Perspectives" The present study attempts to analyze the employers perception on QWL in Small Scale Industrial Units.

\section{Yusuf M. Sidania and Zeina T. Al Hakim (2012)}

"Work-family conflicts and job attitudes of single women: a developing country perspective" In this study, we concentrate on single women because this is an understudied population and because of the unique pressures on them in the Arab context. A Study on the Concept of Quality of Work Life with Respect to Jute Industry - A Literature Review http://www.iaeme.com/IJCIET/index.asp editor@iaeme.com

\section{Indumathy. R, Kamalraj. S (2012)}

In the study -A Study on Quality of Work Life among Workers with Special Reference to Textile Industry in Tirupur District - A Textile Hub\| researcher tried to prove extremely useful for the organization to improve the quality of work life among its workers with the help of the recommendations given by the investigator.

\section{P. SrinivasSubba Rao1, Mrs. P. Suseela Rani (2012)}

in the study "Participative Management in Post Liberalisation- A case study of Indian Jute industryll researchers reveals that post liberalization employers recognized the importance of participative management which improve the operational efficiency of the employees and maintain cordial industrial relations.

\section{HajiehRajabiFarjad, ShahrnazVarnous (2013)}

in the study -Study Of Relationship Of Quality Of Work Life (Qwl) And Organizational Commitment\| researchers study is about the relationships between independent variables (dimensions of QWL, salary and allowances, health security and work conditions, growth opportunities and future development, balance between work and other life aspects, cooperation and significant social aids, social cohesion in work, development of human capabilities) and dependent variables showed that health security and work conditions and development of human capabilities had the most effect on organizational commitment; also, balance between work and other life aspects and salary and allowances had the least effect on organizational commitment.

\section{RESEARCH METHODOLOGY}

Research is a diligent and systematic inquiry or investigation into a subject in order to discover or revise facts, theories. applications etc. Methodology is the system of methods followed by particular discipline. Thus research methodology is the way how we conduct our research. As thos research collected data through structured Questionnaire with 100 sample size and convenient sampling technique used for the study.

\section{RESEARCH DESIGN}

Research design is a basic plan which guides the data collection and analysis phases of the project. it is a frame work, which specifies the type of information to be collected, the resource date collection procedure. The research design adopted for this study is "Descriptive research". The Descriptive research does not fit neatly into the definition of either quantitative or qualitative research methodologies, but instead it can utilize elements of both, often within the study. The term descriptive research refers to the type of research question, design and data analysis that will be applied to given topic. Descriptive statistics tell, what is, while inferential statistics try to determine cause and effect.

\section{DATA ANALYSIS AND INTERPRETATION RULES AND REGULATIONS}

\begin{tabular}{|c|c|c|}
\hline $\begin{array}{c}\text { RULES AND } \\
\text { REGULATIONS }\end{array}$ & $\begin{array}{c}\text { NO OF } \\
\text { RESPONDENTS }\end{array}$ & $\begin{array}{c}\text { \% OF THE } \\
\text { RESPONDENTS }\end{array}$ \\
\hline VERY GOOD & 65 & 65 \\
\hline GOOD & 35 & 35 \\
\hline FAIR & 0 & 0 \\
\hline TOTAL & 100 & 100 \\
\hline
\end{tabular}

\section{INTERPRETATION:}

The above table shows that $65 \%$ of the respondents has told they would join the company with very good rules \& regulations, $35 \%$ of the respondents has told they would join the company with good rules \& regulations and $0 \%$ of respondents told fair.

\section{CHART NO - RULES AND REGULATIONS}

\section{RULES AND REGULATIONS}

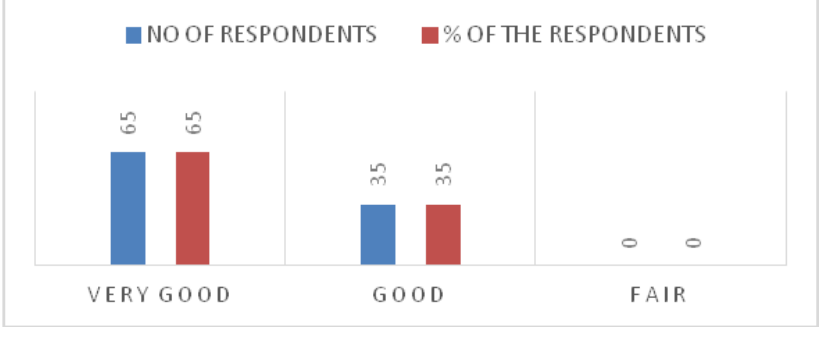

\section{CONCLUSION:}

High performance work practices provide a number of important sources of enhanced organizational performance.HR systems have important, practical impacts on the survival and financial performance of firms and on the productivity and quality of work life of the people in them. Through this Study we came to known how the workers select their company and what are their preferences in the company. This study was conducted in tirupur to known the workers preferences. The workers seek for the company which could help the workers in promoting themselves. For 
the purpose of the study, data were collected through a questionnaire. The data's collected were classified and presented in the form of tables. The result of this research can be a right solution for the worker feelings and worker preference and selecting the company.

\section{REFERENCES:}

[1] Susan E. Myrden et al., Journal of Organizational Effectiveness: People and Performance Employer-brand equity, organizational attractiveness and talent management in the Zhejiang private sector, China
[2] TingTing Jiang et al., Journal of Technology Management in China Service differentiation: A self-image congruency perspective on brand building in the labor market

[3] Tor W. Andreassen et al., Journal of Service Management Linking dimensions of employer branding and turnover intentions

[4] Vaneet Kashyap et al., International Journal of Organizational Analysis Breach or bridge your career? Understanding the relationship between career plateau and internal employability 